Social Policy \& Administration issn 0144-5596

DOI: $10.1111 /$ spol.12289

VoL. 51, No. 2, March 2017, PP. 308-327

\title{
Irish Flex-insecurity: The Post-crisis Reality for Vulnerable Workers in Ireland
}

\section{Mary P. Murphy}

National University of Ireland Maynooth, Dublin, Ireland

\begin{abstract}
Institutional reconfigurations of Irish welfare architecture and specific policy regimes including social security, labour activation and employment regulation have reshaped the contemporary low-paid labour market with more focus on flexibility than security. Irish workers, particularly women, young people and vulnerable migrant workers are more likely to experience a form of labour market precarity we term 'flex-insecurity'. This Irish form of flex-insecurity occurs in a highly globalized, segmented and gendered production regime. A particular model of competitiveness supports light touch regulation, while government procurement policy and tendering practices promote a flexible and low-paid labour force. Case studies demonstrate how the institutional reconfiguration of income support, labour law and work-first activation policy impact on mothers, vulnerable migrants and young people, disempowering these workers. The social politics of change is difficult, despite growing awareness of the extent and impact of these forms of work and some solidarity for and with these vulnerable workers, there remains considerable resistance to implementing policies to address the growing problem of precarious work.
\end{abstract}

\section{Keywords}

Ireland; Precarity; Toung people; Women; Migrants; Welfare architecture

\section{Introduction}

This article explores how, over the last two decades, institutional reconfigurations of Irish welfare architecture reshaped the contemporary workplace for many workers, particularly women, young people and vulnerable migrants. It focuses in particular on how income support policy and work first activation combine with weak labour legislation to disempower vulnerable workers and promote different forms of labour market precarity. This Irish form of 'flex-insecurity' occurs in a highly globalized, segmented and gendered production regime (Murphy and Loftus 20I5).

Author Email: mary.p.murphy@nuim.ie 
Focusing on the contribution of social policy systems to labour dualization (Fersch 2013; Gibb 2009) the article examines how recent institutional reconfigurations of Irish welfare architecture combine to enable precarious forms of employment (Moran 20I6). Various methodological approaches are utilized including literature reviews, development of a schema to explore the concept of 'flex-insecurity', analysis of employment trends and policy developments, qualitative post-crisis research into experiences of low-paid workers in the case of low-income mothers and young people in internships, working conditions of migrant domestic workers and observations from policy processes.

The first section locates the article in labour precarity and labour dualism literature (Gibb 2009; Daly 20I0; Wickham and Bobek 20I5), introduces the concept of 'flex-insecurity', develops a schema to explore flex-insecurity and discusses the drivers behind this change. The second section interrogates the employment and low-paid landscape in Ireland highlighting the disproportionate presence of women, vulnerable migrants and young people amongst the low-paid. The third section briefly sketches recent reconfiguration of social security and labour activation policy and shifts in employment regulation. The fourth section introduces three short case studies to demonstrate how welfare architecture works in different ways to shape and constrain labour market possibilities of vulnerable workers and to highlight the variegated experiences and intersectionality of this diverse group. The first case study examines how low-income employment is often negotiated through and shaped by gendered income support rules (Murphy 20I2, 20I6b). The second examines young people's interaction with the low quality and weakly monitored unpaid labour market internship, JobBridge (Murphy 20I5), while the third explores the experience of vulnerable Irish migrant workers in the unregulated home care sector where employers exploit the employee's vulnerable legal status and the absence of adequate employment regulation (MRCI 20I5b). The concluding section draws on the author's participation in various policy processes and submissions to parliamentary committees and policy consultations to examine the social politics of low-pay in Ireland.

\section{Labour Precarity, Dualism and Flex-insecurity}

This section aims to theoretically frame the article, first clarifying the term flexicurity and then introducing the term flex-insecurity. A systematic schema is developed from flexicurity literature to guide subsequent empirical investigation of the research question - how shifts in Irish welfare architecture combine to produce Irish flex-insecurity. Flexicurity originated as a policy framework in Denmark and The Netherlands in the early I990s and was defined by Wilthagen and Tros (2004:4) as:

a policy strategy that attempts, synchronically and in a deliberate way, to enhance the flexibility of labour markets, the work organisation and labour relations on the one hand, and to enhance security - employment security and social security - notably for weaker groups in and outside the labour market. 
The concept of transitional labour markets (or steps in individual employment trajectories) is linked to flexicurity in the sense of enabling flexible and positive transitions between decent work and periods of unemployment (Schmid and Gazier 2002); in theory, transitions are cushioned by generous welfare schemes but relatively high levels of conditional activation (Viebrock and Clasen 2009).

Each country has its own specific forms and mix of security and flexibility. While the concept of flexicurity guided the European Employment Strategy, pre-crisis Europe experienced a shift towards more precarious and poorer quality employment (Gibb 2009) and dual labour markets with high degrees of polarization between secure and insecure workers (Lewis 2OII; Wickham and Bobek 2OI6). Leschke (2OII: I62) argues European policy shifted from flexicurity to stress employment growth over job quality and social cohesion; Ireland was no exception (Daly 20IO; Dobbins 20IO).

This happened alongside a more conditional welfare regime, retrenchment or recommodification of social security, and deregulation at the margin of the labour market (Bettio et al. 20I2). Drawing on Berton et al.'s (2OIO) description of Italian flex-insecurity, Murphy and Loftus (20I5) termed similar Irish experiences as Irish 'flex-insecurity'. If flexicurity features good jobs, generous welfare and a human capital oriented but conditional activation policy, then 'flexinsecurity' features poor jobs, less generous welfare and a more conditional work-first activation strategy (Berton et al. 20IO). Darmon and Perez (20IO: 84) associate recent labour market changes with recommodification of labour and mobilization of a new form of 'floating' more portable and flexible employees who are required to perform 'standby-ability' (Bengtsson 20I4). The argument is that more work-first activation, decreased social protection, and light touch labour regulation interact to create more negative outcomes for the vulnerable workers. To further examine flex-insecurity, we borrow from the 'flexicurity' literature focus on three institutions: the labour law, the unemployment insurance regime and the labour market policies (Schmid and Gazier 2002), and which understands the 'security' aspect of the flexibility-security nexus as job, employment, income and combination ${ }^{\mathrm{I}}$ security (Wilthagen and Tros 2004: 6). For reasons of space, we omit consideration of employment and combination security and in the third section we briefly outline recent changes in Irish social security and activation (income security) and labour regulation market regime (job security). We focus primarily on postcrisis changes, the period in which the most significant shifts in income and employment security policies occurred or intensified in scope and impact.

While these patterns emerge across Europe, there are specific Irish demand side drivers of precarious employment. Ireland appears consistent with Heery and Salmon's (2000) 'insecurity thesis' where Anglo Saxon states, driven by the global economy, the economic short-termism of financial markets and an appetite for deregulation, create an overall insecurity in the labour market. Quite specific Irish determinants include the crucial role of Foreign Direct Investment (FDI) and the human resource and production policies of global companies (Wickham and Bobek 20I6). Within the context of the EU employment strategy and regulatory framework, Ireland approaches employment policy with an overall 'light touch' ideology which facilitates lax 
regulation, weak oversight and union-free workplaces enabling Ireland adopt a low-road strategy of competing on cost rather than quality (Hickman and Dundon 20I6). Just-in-time production processes and service models are a key feature of international franchise contracts, leaving sub-contracting service providers little option other than to minimize production costs and maximize production flexibility. O'Sullivan et al. (20I5) explain atypical and precarious employment as an outcome of various practical drivers, including increasing levels of work during non-standard hours, requirements for flexibility in demand-led services, absence of an accessible, affordable childcare system, current employment legislation and particular resourcing models of education and health services. Some sectors appear particularly vulnerable. Wickham and Bobek (20I5) identify an increase in 'bogus self-employment' which they attribute to cost saving initiatives by construction firms seeking to reduce direct employment costs. Of the 5.8 per cent of Irish employees who work 'variable' hours, the highest proportion are employed in variable part-time hours, low-hours and non-standard hours in the wholesale/retail, accommodation/food and health and social work sectors. The crisis has had a direct impact. Public and voluntary sector cuts have shifted Ireland's public sector resource model towards greater use of service level agreements. The increased use of competitive tendering and procurement has increased the use of hybrid and low-hour contracts. Increased privatization also creates downward pressure on terms and conditions of private sector employees as tenderers seek to reduce costs (CWI 2OI5). Many public bodies, private sector companies including retail multiples, and charities have also embedded new forms of internships in their human resource model, which in turn creates unfair competition and places downward pressure on wages (Murphy 20I5).

\section{Low-pay, Part-time and Precarious Work in Ireland}

These drivers have interacted with the changing welfare architecture to impact on the nature of Irish employment. This section proceeds by first examining Irish employment trends, the changing quality of Irish employment, the use of 'if and when' contracts, and the extent of low-pay in Ireland.

\section{Working time trends, part-time and temporary employment}

From 20I4, the Irish economy experienced employment growth. The increase in total employment of $46,900(+2.4$ per cent $)$ in the year to QI 2016 was represented by an increase in full-time employment of 30,700 $(+2 . \mathrm{I}$ per cent) and an increase in part-time employment of $16,300(+3.7$ per cent), a total I,636,400 employees, up 37,900 (+2.4 per cent) over the year. Wickham and Bobek (20I6) note overall improvement in the quality of employment albeit alongside a general rise in employment insecurity caused by growing de-institutionalization of the employment relationship. Not all temporary or part-time jobs are bad jobs (54 per cent, above the European average, of Irish temporary workers are in high-skill jobs). It is when involuntary low hours, part-time variable and temporary contracts combine with low-pay that workers experience precarious conditions. 
The incidence of part-time work Ireland is high at 24.4 per cent in 2013 compared to I4.I per cent for the Organisation for Economic Co-operation and Development (OECD) (20I6). Numbers working in variable part-time hours fell slightly from I998 to 2007, almost doubled between 2007 and 2014 and showed a slight decline to 2016 , suggesting the crisis was a clear driver and that, post-crisis, this trend may be in reverse. The overall incidence of temporary workers (including seasonal workers and fixed-term contracts) in the workforce in Ireland rose from 8 per cent in 2008 to IO per cent in 2OI3, but compares well with an OECD average of II .I per cent. However, the share of temporary employment for the I5-24 age group rose from I 2 per cent in 2007 to 32 per cent in 20I3, suggesting a structural issue for youth employment (OECD 20I6). While 44 per cent of the low-paid work 35 hours or more per week, relative to employees overall, the low-paid are more concentrated in low-hours work with 25 per cent working less than 20 hours per week and more likely to be on a temporary contract (I6.3 per cent) than overall workers (8.4 per cent) (Collins 20I5). O'Sullivan et al. (20I5) find the proportion working part time because they could not find full-time work is higher in Ireland (4I.4 per cent) than in the EU (29.6 per cent in EU28), and the proportion of part-time employees who want to work more hours is higher in Ireland (28.7 per cent) than the EU (22.2 per cent in EU28). LPG (20I6: 34) found men did not experience the overall decrease in involuntary part-time employment during the period 20I3-I4.

Globally, technical change is increasing the number of both good (lovely) and bad (lousy) jobs (Goos and Manning 2007). Labour market segmentation limits transition or progression from temporary to permanent contracts of employment (OECD 2OI4). This is particularly the case in Ireland from 2OII to 20I4 where FDI sectors maintained growth in high-tech manufacturing and new internet services alongside growth in low-paid jobs (Wickham and Bobek 20I6: I9; Broughton and Welz 20I3). Post-crisis, new Irish jobs are in fact disproportionately highly skilled; however, processes of privatization and marketization are also turning some previously 'good bad' jobs into 'bad' jobs, with less security, low and irregular pay and low trade union organization (Flecker and Hermann 20II). Different employment patterns dominate in certain sectors. Wickham and Bobek's (20I6: 7) sectoral analysis in finance, construction, hospitality and information technology found 'bad' jobs in all four sectors, and most crucially that 'flexibility is now enforced on workers'. In 20I5, 38 per cent of the Irish construction sector were in 'self-employment' but 7I per cent of this group had no employees, a significant number of whom may be 'bogus' self-employed. In Irish thirdlevel education, those on temporary contracts are 'suppressed upon expiration' (Courtois and O'Keefe 2OI5: 43). O'Sullivan et al. (2OI5), despite data deficits, found widespread use of types of 'if and when' contracts.

\section{How many are low-paid and who are they?}

Low-pay has been growing in Ireland since 2004. Ireland has one of the highest incidences of low-pay in the OECD and is the most unequal for market income of all OECD countries (OECD 2OI5). Collins (2OI5), using 2013 
SILC data, found 30.3 per cent of employees (approx. 400,000) lie below the Eurostat low-pay threshold (two-thirds of median hourly earnings) of $€$ I2.2O. Irish employees in precarious or non-regular employment are young, work in low-skilled occupations, and are more likely to be female, while 22 per cent have not completed secondary education (OECD 20I5). More than one-third of the low-paid are aged under 30 and between 60 per cent and 65 per cent of the low-paid are aged under 40, but low-pay also extends across the life cycle with many workers low-paid over long periods of working life (Broughton and Welz 20I3). I7.8 per cent of full-time workers were lowpaid in 2000, this rose to 23.3 per cent in 2013 (Collins 20I5). High female low-pay rates are not new, only 20 per cent of Irish women earn more than $€ 50$,o00 per year, 60 per cent were low-paid in 20I3, and in 20I4, 74.2 per cent of those on the minimum wage were women (LPG 20I6). However, the crisis occasioned growth in male low-paid employment so that 40 per cent of low-paid are now men (NERI 20I6). By 20I3, one in every five full-time male employees was low paid and involuntary male part-time underemployment doubled during the crisis period. While many non-Irish nationals (I3.9 per cent of all employees) are in well paid employment, in 20I4, 26 per cent of all minimum wage employees were non-Irish nationals (LPG 20I6). Almost one in four low-paid are in the wholesale and retail sector, with almost one in six in the accommodation and food sector.

\section{Income Security and Job Security in Ireland}

Using the schema identified in the first section, we examine reconfigurations that hasten flex-insecurity, first examining Irish social security and activation changes (income security) then examining employment regulation (job security).

\section{Income security}

Recent social security cuts have made income support less decommodifying so that claimants are more likely to have to engage in paid employment. Three types of changes are discussed and summarized in table I: (I) changes that recommodify welfare; (2) activation changes that increase conditionality; (3) changes to enable access to in work compensation.

Recommodifying welfare. Irish social assistance rates remain at 2OII rates, are regarded as relatively generous and, as transfers, have proven efficacious at reducing high levels of market inequality and mitigating relative poverty (Watson et al. 20I2). Nonetheless, working-age claimants experienced a significant range of austerity cuts. The Christmas Bonus was abolished in 2009. Budgets 2OIO and 2OII directly reduced the generosity of income payments by €I6 per week. Together these reduced by IO per cent the value of working-aged payments. During 2009-IO, social assistance payments for unemployed people aged under 25 were halved, and in 20I4, further age-related cuts were implemented. Table I outlines a series 
Social Policy \& Administration, Vol. 5I, No. 2, March 2017

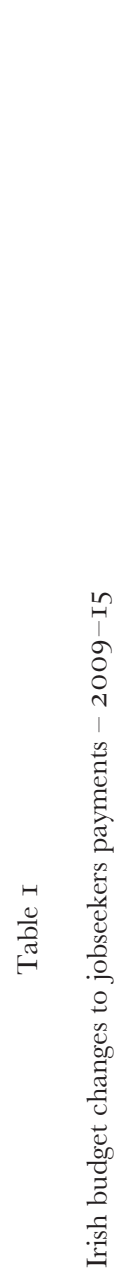

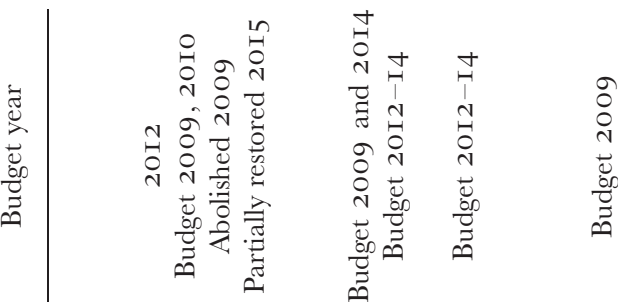

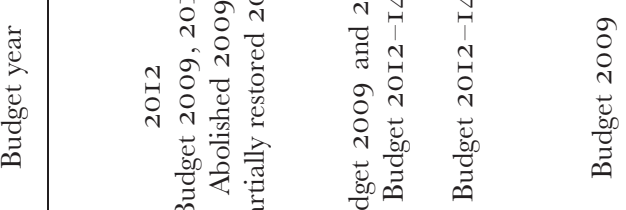

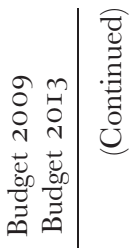

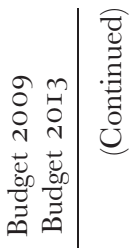

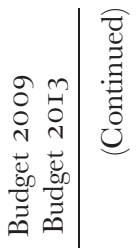

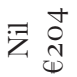

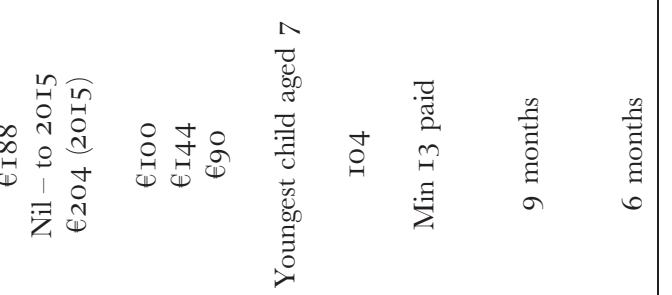

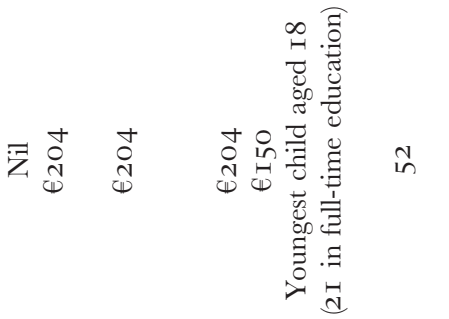

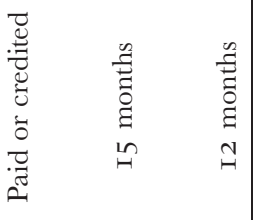

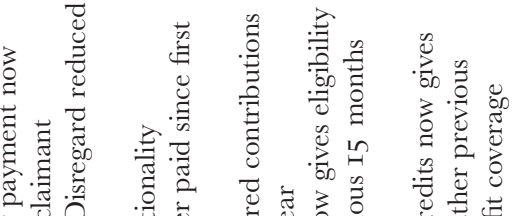

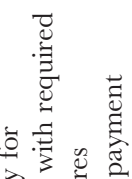

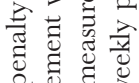

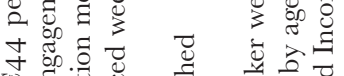

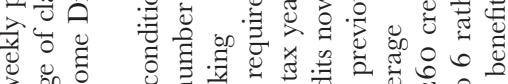
o d 屯

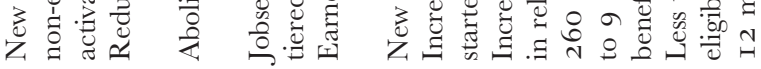


Social Policy \& Administration, Vol. 5I, No. 2, March 20 I7

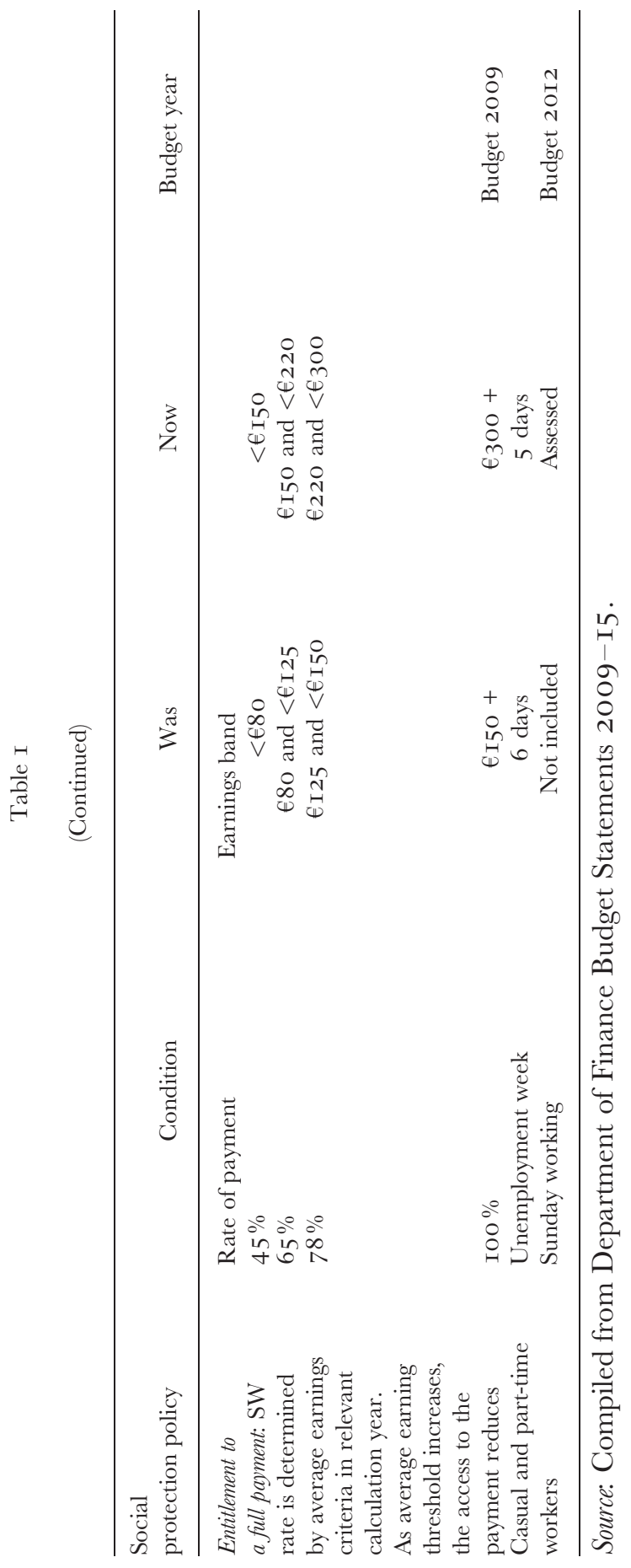


of changes in social insurance rates, eligibility and entitlement criteria implemented during the period 2009-I4. These followed similar restrictions in previous 'mini' crisis budgets, the Dirty Dozen cuts in 1992 and the Savage Sixteen in 2004, which together constitute a longer-term pattern of decommodifying Irish welfare (Murphy 2009). More onerous eligibility criteria also made it harder to qualify for in-work benefits, excluding more low-paid and precarious workers from social protection (Murphy and Loftus 20I5). The fourth section discusses a range of cuts to the One Parent Family Payment (OFP) for lone parents.

Activation. Greater conditionality has been associated with in-work poverty. Irish labour activation policy has converged towards a work-first conditional regime with new penalties and sanctions and a broader range of job-seeking requirements applied to a larger section of the working-age welfare population (Murphy 20I6a). Ireland is historically considered to be 'light' in the implementation of conduct conditions (Murphy 20I6a). However, conduct conditions intensified during the crisis period with three specific reforms increasing the job search obligations of unemployed jobseekers, lone parents and young people, and extending the range of penalties for failing to meet these new obligations (Murphy 20I6a). Early crisis attempts to increase labour market conditionality for all working-age claimants lost political momentum, but the reform proceeded for the least politically protected group, lone parents, and may yet be implemented for partners and people with disabilities under the activation strategy Pathways to Work 20I6-202O (DSP 20I6). From late 20I5, the introduction of 'JobPath' a pay-by-results privatization of public employment services (PES) will further increase the use of sanctions. In 20I7, jobsearch obligations will be extended to claimants in part-time employment and in receipt of in-workbenefits (Murphy 20I6a), and like the UK Universal Credit, in-work conditionality may ultimately require part-time workers to access multiple part-time jobs.

In-work compensation. Crisis-related labour market changes including lower hours of employment led to increased numbers of precarious workers reliant on inwork compensation. The state, while recommodifying welfare claimants, then had to increase the use of state subsidies to make their low-hours or low-paid work sustainable. Increased interaction between the social welfare system and low-paid work was evident before, but intensified during the crisis. Figure I shows how expenditure on, and the numbers claiming, Family Income Supplement - the main Irish in-work-benefit available to families with children who reach a threshold of I9.5 hours paid employment per week increased during the crisis (from 28,223 claims in 2010 to 44,I59 in 20I3, and 50,306 in 20I4). Improved programme design and information campaigns account for some of this increase, but declining hours worked accounts for more of the increased numbers. Figure 2 shows a sharp rise in the numbers of low-hour or casual workers allowed retain a portion of the weekly jobseekers' payment (provided they do not exceed 
Figure I

Growth in Family Income Supplement expenditure and claims 2002-I5

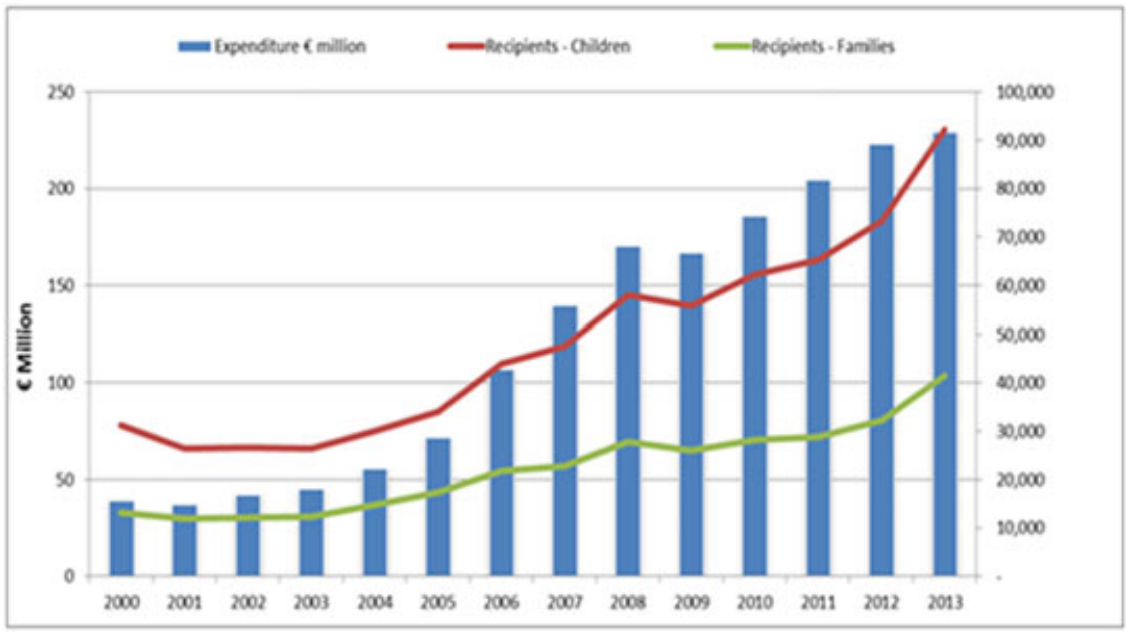

Source: Collins and Murphy 20I6: 77. [Colour figure can be viewed at wileyonlinelibrary.com]

Figure 2

Growth in casual and part-time workers on the Live Register, 2002-I5

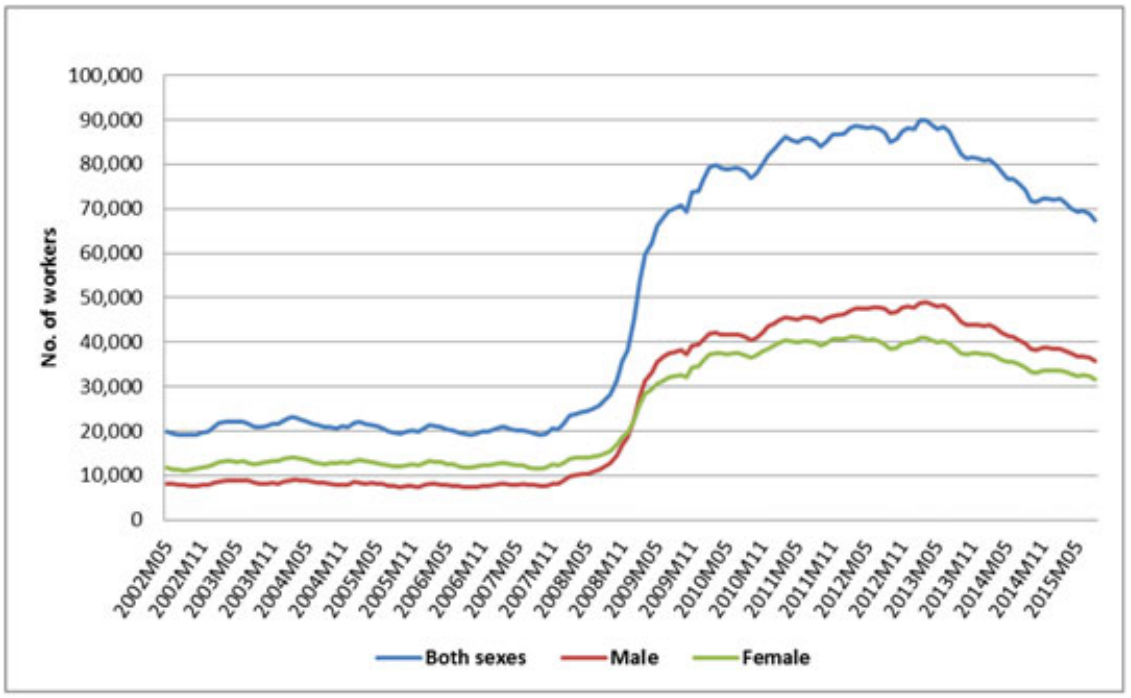

Source: Collins and Murphy 20I6: 79. [Colour figure can be viewed at wileyonlinelibrary.com] (C) 2017 John Wiley \& Sons Ltd 
three days of paid employment per week). In what may be a post-crisis shift, the numbers availing of this facility peaked in 2012 and subsequently dropped. A number of atypical workers fall between these two in-work compensation schemes, working more than three days but less than I9.5 hours per week (Murphy and Loftus 2015) and unable to access social protection.

\section{Employment regulation}

Even before the crisis, Ireland had insufficient safeguards in the form of employment protection legislation (EPL) to limit negative and perilous forms of atypical work; before, during and after the crisis, there is evidence of weak implementation, oversight and compliance of labor regulation (Turner and O'Sullivan 2013: Hickman and Dundon 2016). During the crisis, many 'anchor points' of Irish employment protection were removed in a Troikainduced reform of Ireland's employment regulation, industrial relations bodies and wage-setting mechanisms (Wickham and Bobek 20I6; Hickman and Dundon 20I6: 205-6). A regressive reform in the name of flexibility was the restructuring of the Joint Labour Committees (JLCs) to remove rights to basic working conditions including overtime and Sunday working premiums. This was a 'considerable diminution' of conditions of employment with potential to create 'a race to the bottom in low-pay sectors of the economy' (Turner and O'Sullivan 2OI3: 2I6).

In figure 3, Ireland scores relatively poorly on strictness of EPL, below the OECD average on three out of four indicators: protection of permanent workers against individual and collective dismissals (2.07); protection of permanent workers against (individual) dismissal (I .5O); specific requirements for collective dismissal (3.5); and in the bottom six of OECD states for regulation on temporary forms of employment (I.2I); with a slight worsening in

Figure 3

Employment protection in Euro Area 2008 and 2013

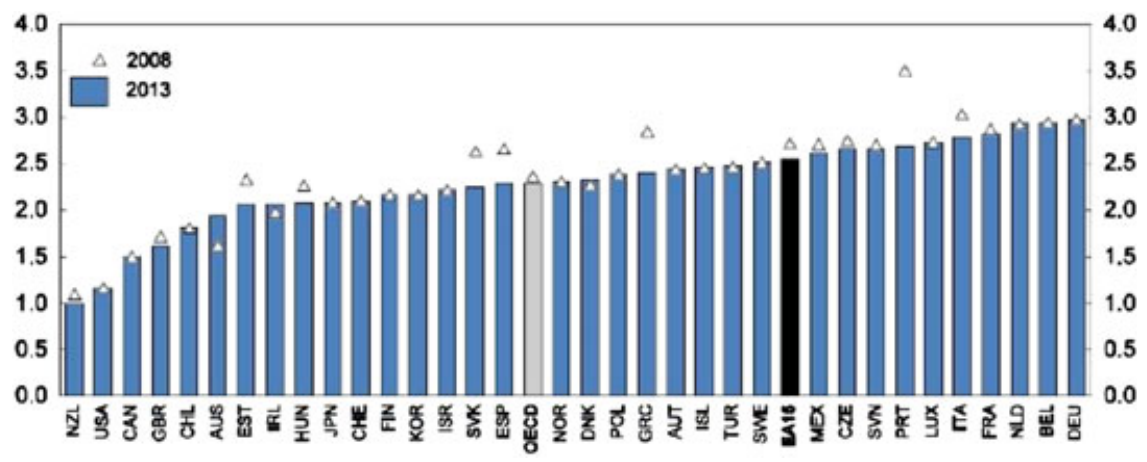

Source: OECD 2013. Notes: Index scale: o $=$ least restrictive; $6=$ most restrictive. 
EPL or labour market liberalisation from 2008 to 2013 (OECD 20I6). In addition, seeing opportunity in crisis, employers have taken advantage of light or absent EPL to advance more precarious employment practice. Three examples suffice: (I) weak enforcement and monitoring of taxation compliance fails to protect against the phenomena of bogus self-employment, where work offers in some sectors, particularly construction, are contingent on the would-be worker becoming self-employed (Wickham and Bobek 20I6). Despite the collapse in employment in the Irish construction sector, the number of solo self-employed in the sector is almost the same as at the height of the boom (Wickham and Bobek 2OI6); (2) Ireland also fares poorly on regulating internships and traineeships, particularly failing to regulate for social protection, remuneration and duration (EC 2OI2). This absence of protection enabled the state to develop active labour market measures such as unpaid internships which legitimated exploitative practices in the public, private and voluntary sectors (Murphy 20I5); (3) legislative reforms to protect workers may have triggered new employment practices as employers sought to avoid the implications of such EPL (O'Sullivan et al. 2OI5). The Organization of Working Time Act, I997 attempted to protect against zero-hour contracts by including a protective 'minimum hour requirement'. Over time, this provision was bypassed by employers through the use of 'if and when' contracts (O'Sullivan et al. 2OI5). Similar in outcome to UK zero-hour contracts, 'if and when' contracts offer no guaranteed hours of work but, unlike fixedhour contracts, impose no legal obligations on the worker to accept the offer of any particular rota of work. In practice, however, workers feel they will be penalized if they refuse to accept 'hours' while at the same time are often not offered sufficient hours to make employment sustainable (Loftus 2012).

Having set the context for income and job security or income support recommodification, work-first activation and weak labour market regulation, the next section examines how welfare architecture combines to influence and constrain the labour market possibilities and lived reality of vulnerable workers in Ireland.

\section{The Labour Market Reality of Women, Vulnerable Migrants and Young People}

This section examines the post-crisis labour market reality for groups Turner and O'Sullivan (2013) identify as disproportionately likely to be covered under sectoral minimum wage agreements: women, young people, nonnationals and part-time workers, but also seeks to examine differences within these heterogeneous groups. We first examine the experience of social welfare dependent mothers whose labour market participation is negotiated through, and shaped by, gendered income support rules, we then examine how young people without choice are exploited in unpaid labour market internships, before turning to the experiences of vulnerable migrant workers working in a segmented labour markets without adequate worker protection.

The arguments of employer organizations that flexible contracts suit certain employees are contested by quantitative and qualitative evidence that many part-time workers want but cannot access more part-time hours 
(O'Sullivan et al. 20I5; Loftus 20I2; Moran 20I6). Trade unions and nongovernmental organizations (NGOs) stress the negative impact on working and personal life of these unpopular contracts. The rate of material deprivation of minimum wage workers is $3 \mathrm{I} .8$ per cent (over I 2 per cent higher than the general rate of employees experiencing deprivation). Of those at risk of poverty, I4 per cent are at work, these 'working poor' represent 6.I per cent of all workers, while 2.4 per cent of workers are in consistent poverty (CSO 2OI4). Unpredictable work incurs additional costs on households and individuals regarding travel, fuel, personal costs and childcare (Collins et al. 20I2). 'Floating' forms of work are more costly in terms of finance and stress; they require contingency planning and stand-by arrangements without guaranteed work or income (Darmon and Perez 2OIO).

\section{Women}

Non-standard' work, especially marginal employment, is often explained as the joint result of a need for women to supplement a male breadwinner model and companies' need for flexible labour input. While male workers increasingly find themselves in precarious work, it is still the case that more women than men work one to eight, nine to I8 and I9-35 hours per week, and 96 per cent of employees who cite caring responsibilities as the reason for working part-time are women (Collins 2OI5). Primary carers lacking affordable, accessible childcare are unlikely to want unpredictable hours. Many are lone parents or partners/spouses of jobseekers who live in social welfare dependent and low-work-intensity households. At risk of poverty and deprivation, lacking childcare and trapped in very local job markets, they often survive by combining low-hours of part-time work with social welfare income. Managing the interaction between low-paid work, variable hours and social welfare means-testing rules is difficult, necessitating ongoing negotiations with welfare officers, employers and family, often from a situation of powerlessness. To illustrate, a brief account of this complexity and recent change is now offered, drawing attention to the overlap and differences between different categories of low income women.

In Budget 2012 and 2OI3, the Irish Government introduced structural reforms to an existing OFP, a social assistance for payment for lone parents with at least one child aged under I8 (2I if child in full-time education). First, eligibility to OFP was restricted to lone parents with children younger than seven. Second, a higher earnings disregard for lone parents - originally given in recognition of high childcare costs - was to be reduced in four annual cuts of $€ I 5$ to align with Jobseeker's Allowance. Third, jobseeker activation conditions were extended to former OFP recipients, so they are now required to be capable of, available for, and genuinely seek full-time employment. Interaction between earned income and OFP is complex; benefit clawbacks cause significant poverty and unemployment traps (Murphy 2OI4; OECD 20I5: 2). Nonetheless, 34 per cent of these lone parents worked part-time in 2014.

Different rules apply to married or cohabitating social welfare dependent mothers. A jobseeker receives an addition of 70 per cent of the adult rate on behalf of a partner/spouse as long as the partner's/spouse's earnings from 
part-time employment are below a weekly 'dependency' threshold (€IOO in 20I6). Women comprise over 90 per cent of these partners/spouses (Murphy 20I6b). When a partner earns income from part-time employment, her earnings impact not only on the amount of 'addition' paid, but also impact on the overall family payment, the jobseeker claimant and the "partner' are each allowed earn $€ \mathbf{2 0}$ per day before the family welfare payment is reduced by 60 cents for every $€ \mathrm{I}$ earned. While the primary claimant is restricted to three days' part-time work, the partner has no such restriction and can work flexibly across the week. Between 40 and 60 per cent of 'partners' utilized these earnings disregards in 2015, suggesting an embedded pattern of low-paid and part-time work for many partners (Murphy 20I6b).

At one level, these relatively generous (when compared to UK) income disregards make participation in low-paid and low-hours work sustainable for these lone parents and partners. The greater flexibility and capacity to work across the week makes it easier to find part-time work, but employers also exploit such flexibility and stretch hours and tasks across the week, making childcare and labour participation more costly. Variable working hours play havoc with the reality of life on social welfare. Welfare payments have to be constantly renegotiated, workers may not be guaranteed sufficient hours to access in-work-benefits and, as lone parents found, social security rule changes can change the viability of previous employment practices. Child care and family arrangements have to be constantly juggled. We also see inequitable treatment based on the family status of two groups of women, with lone parents pushed towards full-time work and partners in coupled households facilitated to choose whether and how they wish to access paid employment.

\section{Young people}

Intergenerational inequality has been a hallmark of the Irish crisis, with young people likely to experience generational scarring and delayed development of key lifecycle transitions. Young people are not homogenous and class determines their likelihood of emigration, with the better educated and those in employment more likely to emigrate, leaving the less well educated locked into the indigenous or local labour market (CSO 2OI4). Likewise, there is inequality of opportunity in accessing education, training and entry-level work experiences, with better off families more able to mitigate an adult child's low income. Despite higher youth emigration rates, young jobseekers still experience double the rate of unemployment as the $25-65$ age cohort and Irish NEET (young people 'not in employment, education or training') increased significantly from I2.5 per cent in 2007 to peak at 24.I per cent in 2010 (NERI 20I6). Austerity policy decisions halved welfare rates for under-25s and created new forms of entry-level statutory jobs so that young teachers, nurses and state employees have lower wages and poorer terms and conditions than established peers (Courtois and O'Keefe 20I5). Other entry-level jobs have disappeared, sometimes replaced by internships.

Perlin notes that 'young people can hardly believe in a world without internships, part of a brave new economy of intense competition and altered expectations' (Perlin 20I2: 3). In 2OII, the Irish Government established 
'JobBridge' as a temporary labour market internship programme. For a sixor nine-month period, participants receive an allowance of $€ \mathbf{5 2} .50$ per week on top of age-related social welfare entitlements. Light monitoring systems were adopted to lessen obstacles for employers using this largely selfregulating programme. Employers who meet basic eligibility criteria directly recruit and select eligible unemployed applicants. The annual numbers participating in such internships peaked at I2,654 in 20I4, and by the end of 20I5, over 46,500 people had participated in JobBridge. In 2013, the vast majority of participants were aged under 34, 65 per cent had degree level education or higher and 72 per cent had been previously employed full time. Evaluations found monitoring was lax and inadequate; there was evidence of deadweight and displacement of entry-level jobs and persistent complaints about variable quality and poor experiences (NYCI 2OI5). Parliamentary committees, trade unions, NGOs and political parties called for the closure or fundamental reform (Murphy 20I5) of JobBridge. While presented as a voluntary labour market programme, there are nuances in how claimants perceived participation in JobBridge. Economic compulsion means people have little choice but to do what they can to supplement inadequate income (EC 2OI2). In 2OI4, a youth JobBridge First Steps became a (temporary) mandatory requirement of the 2OI4 Youth Guarantee. JobBridge was closed to new entrants in October 20I6, a new work experience programme programme will be launched in 2017 .

\section{Vulnerable migrants}

One in eight people living in Ireland were not born in Ireland. After a sustained period of net emigration from Ireland, summer 2016 saw the return of net migration into Ireland. Migrants constitute a diverse population and, while many are well paid, a significant cohort are concentrated in lowpaid service sectors such as food, retail, health-related services and private households and experience high incidences of labour exploitation and if and when' contracts (LPG 2OI6; MRCI 2OI5a). Highlighting intersectional vulnerability, this section explores how welfare architecture impacts migrant women in the home care sector.

Analysis of the employment conditions of IO9 home care migrant workers found many employed by, and working for, two or more private sector companies on the same day, and paid only for the time spent in each client's home (not for periods of travel), resulting in very low wages (MRCI 20I5b). The study found weak forms of employment contracts without guaranteed hours. It documented high levels of staff turnover and poor terms and conditions such as anti-social hours, as well as high levels of exploitation, contractual issues and discrimination. Workers are reluctant to file complaints for fear of losing hours, clients or jobs, feel undervalued and excluded from decision-making processes, and they experience poor staff morale and work-related stress. Black and ethnic minority workers also experience a heightened risk of racism and discrimination, as some clients refuse services from such workers. Migrant care workers' experience can be contrasted with statutory Health Service Executive home help staff who are predominantly indigenous Irish and who, following 
successful industrial action in April 20I4, now experience trade union monitored guaranteed weekly hours and an annualized-hours contract. We see the variegated experience of different groups of women, with ethnic and legal status determining employment sector and quality of employment.

The three short case studies show how welfare architecture shapes the labour market reality for different workers. Flex-insecurity occurs in a modified male breadwinner gender regime and produces gendered, class and ethnically differentiated outcomes in segregated occupational sectors (Murphy $2016 \mathrm{~b})$. Intersectionality interacts with legally neutral welfare architecture to increase vulnerability to precarity in the case of gender, family status, ethnicity and class. Some groups, although vulnerable, have more personal or structural power to negotiate. Such differential power will partially determine the shape the welfare architecture of the future.

\section{Shaping the Welfare Architecture of the Future: The Social Politics of Irish Flex-insecurity}

This article has argued that, rather than flexicurity, a significant proportion of the Irish labour force experience flex-insecurity where welfare architecture, in design and in implementation, offers less than adequate levels of income and job security so that low-pay, temporary, variable and under-employment is the experience of too many Irish workers. The policy direction is often an outcome of unintended consequences and is not necessarily linear, but the overall pattern is consistent. Working-age social protection commodified while numbers accessing in-work compensation grew and activation intensified conditionality. EPL features of this policy mix existed pre-crisis, but during the crisis inadequate protection, and weak monitoring and implementation provided the opportunity for employers to shift towards legally viable but precarious practices, including bogus self-employment 'if and when' contracts and unpaid internships. The case studies also show how intersectionality matters with class, gender ethnicity and age intersecting precarity. The question now, post-crisis, is whether policy will continue in this direction or whether it can be halted and reversed. Might the increase in variable hours be simply a reversible cyclical outcome of recession or will it be allowed become a structural turn in the mode of production (Collins 2OI5)? There are grounds for both optimism and pessimism in this regard.

Reasons for pessimism include the likelihood that in 2017 precarious workers will experience 'in-work-conditionality' in a privatized PES more likely to implement a more punitive activation policy. Wilthagen and Tros (2004: I6) note the importance of 'positive coordination' and trust in achieving 'negotiated flexibility'. The collapse of Ireland's corporate bargaining structure means a less optimal governance structure to negotiate flexibility and security between relevant actors (Hickman and Dundon 2016). Brexit also provides grounds for pessimism, creating more anxiety about and a stronger focus on maintaining wage competitiveness (LPG 20I6: 20). Optimistically, following Wilthagen and Tros (2004: I8), it is reasonable to assume a more positive economic environment opens up the opportunity for income and job security. There is evidence that precarious workers are organizing. 
There is a growing consensus, for example, that internships be minimized, regulated and compensated, the Government has committed to wind down the JobBridge internship programme and a Low-pay Commission (LPG) was established in 2014 .

It is too early to make a judgement on the experience of the LPC, but commissioned research on the use of variable-hour contracts and the gendered nature of the low-pay has so far realized little in outcomes. The Irish minimum wage real value relative to median wages fell during the crisis period (OECD 2OI5) and since 2OII remained frozen at €8.65. An LPG majority recommendation for a 50 cent increase to $€ 9 . I 5$ was implemented in January 20I6. Minority trade union and NGO reports argued this was well short of the living wage ( $€$ II .65 in 2015 terms). Having been abolished during the crisis, in January 20I4, new JLCis were established to develop sectoral minimum wages for six low-paid sectors: hospitality, catering, retail, contract cleaning, security and agriculture; more constrained in their powers, they have been slow to establish new sectoral minimum wages.

Much can be done to prevent a pattern of embedded flex-insecurity, including sectoral focused reforms, procurement policy, social clauses, investment in enabling activation, childcare and public services. However, given who benefits from such corporate welfare (state-funded internships, in-work subsidies, earned income disregards, light touch regulation and inadequate monitoring and enforcement), vetoes to reforms are strong and it is not clear there is sufficient political will to act. Government faces pressure from employers in particular sectors, but also from those lobbying for overall competitiveness of the Irish economy (McElwee 20I6), and this will intensify in the context of Brexit (LPG 20I6). Dualism also benefits many (middle-class) consumers who manage the stresses of life by availing of cheaper services, including childcare and home care, while working in better regulated and higher paid employment. Segmented labour markets and categorical social welfare systems also create false tensions between groups of workers and claimants which dilute intersectional solidarities across gender, generational, ethnic and class grounds. Differences are exploited when certain workers or claimants are scapegoated in political and public discourse (e.g. lone parents and young people [Murphy 20I4, 20I6a]). Trade unions are weaker, density declined from 54 per cent in I980 to $3 \mathrm{I} .2$ per cent in $20 \mathrm{O} 2$; however, some trade unions are innovating with new forms of organizing in these challenging sectors. Precarious workers have generated solidarity by leading campaigns against precarious work practices in third level education (Third Level Watch); exploitative internships (\#WorkMustPay); labour exploitation of au pairs (Migrants Rights Centre Ireland); and 'if and when' contracts for home-helps (SIPTU). Nonetheless, given the welfare architecture of flexinsecurity, it is not unrealistic to conclude that costs of production seem likely to continue to be pushed onto the low-paid worker with little power or choice but to comply.

\section{Note}

I. Ability to combine employment with other life goals including care. 


\section{References}

Bengtsson, M. (20I4), Towards standby-ability: Swedish and Danish activation policies in flux, International fournal of Social Welfare, 23, SI : S54-S70.

Berton, F., Richiardi, M. and Sacchi, S. (2OIO), 'Flex-Insecurity' in Continental Welfare Regimes: The Case of Italy, Paper presented at the annual meeting of the SASE Annual Conference, Temple University, Philadelphia, PA, USA, 24 June.

Bettio, F. et al. (2OI2), The impact of the economic crisis on the situation of men and women and on gender equality policies - Synthesis Report, Luxembourg: European Union.

Broughton, A. and Welz, C. (20I3), The Impact of the Crisis on Industrial Relations, Dublin: Eurofound.

Central Statistics Office (CSO) (2OI4), Population \& Migration Estimates 2OI4, Dublin: CSO.

Collins, M. L. (2OI5), Earnings and Low-pay in the Republic of Ireland: a profile and some policy issues, NERI Working Paper, 2015/ No. 29, Dublin: NERI.

Collins, M. and Murphy, M. P. (20I6), Activation for what? Employment or a lowpay economy. In M. P. Murphy and F. Dukelow (eds), The Irish Welfare State in the 2I st Century: Challenges and Changes, Basingstoke: Palgrave.

Collins, M. L., MacMahon, B., Weld, G. and Thornton, R. (2012), The Cost of Work: Insights from Minimum Income Standards Research for Ireland, May 20I2, Dublin: NERU.

Community Work Ireland (CWI) (20I5), In Whose Interests? Exploring the Impact of Competitive Tendering and Procurement on Social Inclusion and Community Development in Ireland, Galway: CWI.

Courtois, A. and O'Keefe, T. (20I5), Precarity in the ivory cage: Neoliberalism and casualisation of work in the Irish higher education sector, Fournal of Critical Education Policy Studies, I3, I : 43-66.

Daly, M. (20IO), Ireland. In-work Poverty and Labour Market Segmentation. A Study of National Policies. Peer Review in Social Protection and Social Inclusion and Assessment in Social Inclusion, Brussels: European Commission.

Darmon, I. and Perez, C. (2OIO), 'Conduct of conduct' or the shaping of adequate dispositions? Labour market and career guidance in four European countries, Critical Social Policy, 3I, I: 77-IOI.

Department of Social Protection (DSP) (20I6), Pathways to Work 20I6-2020, Dublin: DSP.

Dobbins, T. (2010), Ireland: Flexible Forms of Work: 'Very Atypical' Contractual Arrangements, Brussels: European Working Conditions Observatory.

European Commission (EC) (2OI2), Study on a comprehensive overview on traineeship arrangements in Member States, Brussels: EC.

Fersch, B. (20I3), 'German angst' vs 'Danish easy going'? On the role and relevance of insecurity and uncertainty in the lives of freelancers in Denmark and Germany, Sociology, 46, 6: II 25-39.

Flecker, J. and Hermann, C. (2OII), The liberalization of public services: Company reactions and consequences for employment and working conditions, Economic and Industrial Democracy, 32, 3: 523-44.

Gibb, E. (2009), Precarious employment - causes, drivers, challenges and responses; a literature review. In J. Evans and E. Gibb (eds), Moving from Precarious Employment to Decent Work, Geneva: ILO, GURN, pp. I5-69.

Goos, M. and Manning, A. (2007), Lousy and lovely jobs: The rising polarization of work in Britain, Review of Economics and Statistics, 89, I: II8-33.

Heery, E. and Salmon, J. (eds) (2000), The Insecure Workforce, London: Routledge.

Hickman, E. and Dundon, T. (20I6), Reform of joint regulation and labour market policy during the current crisis: The manufacturing sector in the Republic of 
Ireland. In A. Koukiadaki et al. (eds), Foint Regulation and Labour Market Policy during the Crisis, Brussels: ETUI, pp. 205-56.

Leschke, J. (2OII), Transition from unemployment to work and the role of active labour market policies during the Lisbon strategy period and the economic crisis, German Policy Studies, 7, I: I35-70.

Lewis, P. (2OII), Upskilling the workers will not upskill the work. Why the dominant economic framework limits child poverty reduction in the UK, Fournal of Social Policy, 40, 3: 535-56.

Loftus, C. (2012), Decent work? The Impact of the Recession on Low-paid Workers, Dublin: Mandate.

Low-pay Commission (LPG) (20I6), Recommendations for the National Minimum Wage, $L P C$ No 2, Dublin: LPG.

McElwee, M. (20I6), Welcome Address, IBEG Employment Law Conference, Croke Park, Dublin, I2 May.

Migrant Rights Centre Ireland (MRCI) (20I5a), All Work and No Pay; The Experiences of Migrants Working in Ireland, Dublin: MRCI.

Migrant Rights Centre Ireland (MRCI) (20I5b), Migrant Workers in the Home Care Sector: Preparing for the Elder Boom in Ireland, Dublin: MRCI.

Moran, J. (20I6), The social construction of Irish precarity, Unpublished $\mathrm{PhD}$ thesis, Department of Sociology, Maynooth University.

Murphy, M. P. (2009), The politics of cutbacks, Village Magazine, No. 4, May: 30-I.

Murphy, M. P. (2012), The politics of labour activation I980-20IO, Administration, I, 2: $20-32$.

Murphy, M. P. (2OI4), Ireland's lone parents, social welfare and recession, Irish Community Development Law Fournal, 3, 2: 6-20.

Murphy, M. P. (2015), FobBridge - Time for a Change? Proposals to Reform, Resize, Refocus Irish Internships, Dublin: Impact.

Murphy, M. P. (2016a), Low road or high road? The post crisis trajectory of Irish activation, Critical Social Policy, 36, 2: I-I2.

Murphy, M. P. (20I6b), Ode to an invisible woman: Qualified adults or 'partners' in Ireland, Irish Fournal of Sociology, doi: IO.II77/O79I6035I6629088 (accessed 2I November 20I6).

Murphy, M. P. and Loftus, C. (2015), A precarious future: An Irish example of flexinsecurity. In S. O'Riain et al. (eds), Changing Capitalisms: The Changing Worlds and Workplaces of Capitalism, London: Palgrave, pp. I22-38.

National Youth Council of Ireland (NYGI) (2OI5), fobBridge stepping stone or dead end, Dublin: NYGI.

Nevin Economic Research Institute (NERI) (20I6), Quarterly Economic Facts, QI 20I6, Dublin: NERI.

Organisation for Economic Co-operation and Development (OECD) (2013), Employment Protection Index, http://www.oecd.org/els/emp/oecdindicatorsof employmentprotection.htm (accessed II July 20I6).

Organisation for Economic Co-operation and Development (OECD) (20I4), Society at a Glance, Paris: OECD.

Organisation for Economic Co-operation and Development (OECD) (20I5), Employment Outlook Ireland, Paris: OECD.

Organisation for Economic Co-operation and Development (OECD) (20I6), Parttime employment rate and temporary employment indicators, doi: IO.I787/ f2 ad596c-en and doi: IO.I787/75589b8a-en (accessed II July 20I6).

O'Sullivan, M. et al. (2OI5), A Study on the Prevalence of Zero-hours Contracts among Irish Employers and their Impact on Employees, Dublin: Low-pay Commission.

Perlin, A. (2012), Intern Nation: How to Earn Nothing and Learn Little in the Brave New Economy, London: Verso. 
Schmid, G. and Gazier, B. (eds) (2002), The Dynamics of Full Employment: Social Integration through Transitional Labour Markets, Cheltenham: Edward Elgar.

Turner, T. and O'Sullivan, M. (2OI3), Economic crisis and the restructuring of wagesetting mechanisms for vulnerable workers in Ireland, Economic E̊ Social Review, 44, 2: 197-219.

Viebrock, E. and Clasen, J. (2009), Flexicurity and welfare reform: A review, SocioEconomic Review, 7, 2: 305-3I.

Watson, D., Maître, B. and Whelan, C. T. (2012), Work and Poverty in Ireland, Dublin: ESRI and Social Inclusion Division of Department of Social Protection.

Wickham, J. and Bobek, A. (20I5), Enforced Flexibility? Working in Ireland Today, Dublin: TASC, http://www.tasc.ie/download/pdf/enforcedflexibilityfinal.pdf (accessed 2I November 20I6).

Wickham, J. and Bobek, A. (20I6), Enforced Flexibility? Working in Ireland Today, Dublin: TASC.

Wilthagen, T. and Tros, F. (2004), The concept of 'flexicurity': A new approach to regulating employment and labour markets, Transfer: European Review of Labour and Research, IO, 2: I66-86. 